\title{
Two hay: concentrate ratios in total mixed rations for cows at different stages of lactation ${ }^{1}$
}

\author{
Paul F. Randel ${ }^{2}$
}

\begin{abstract}
Different proportions of forage to concentrate in total mixed rations (TMR), for cows in earlier and later lactation, were tested in a two-phase (I and II) experiment. During phase I (120 days), nine control cows rotationally grazed unfertilized, dry season, grass pastures and were group-fed supplemental concentrates (treatment $A$ ), while their pair mates in confinement received a TMR of $40 \%$ grass hay, $25 \%$ of which was finely ground (FG) and $15 \%$ coarsely chopped (CC), and $60 \%$ concentrates (treatment B). During phase II ( 37 days), the TMR was $50 \%$ hay ( $35 \% \mathrm{FG}, 15 \% \mathrm{CC}$ ) and $50 \%$ concentrates; control (A) as previously. Mean results for $A$ and $B$ in I were: daily yield of milk, 16.1 vs. $17.8 \mathrm{~kg}$, and of $4 \%$ fat-corrected milk (FCM), $11.4 \mathrm{vs}$. $14.9 \mathrm{~kg}$; percentage concentration of milk fat (MF), 2.05 vs. 2.91 and protein, 3.13 vs. 3.19; daily liveweight (LW) gain, 0.20 vs. $0.03 \mathrm{~kg}$. Treatments differed $(P=0.01)$ in FCM yield and MF. Dry matter intake (DMI) in $B$ was $18.2 \mathrm{~kg} /$ day and feed efficiency (FCM yield/DMI), 0.82; for A, DMI from concentrates was $7.3 \mathrm{~kg} /$ day and partial efficiency (FCM yield/concentrate DMI), 1.57. In II, A and $B$ means were: milk yield, 13.7 vs. $15.5 \mathrm{~kg} /$ day; FCM yield, 11.7 vs. 13.6 $\mathrm{kg} /$ day; MF, 3.07 vs. 3.22 ; LW gain, 0.30 vs. $0.75 \mathrm{~kg} /$ day, without significant differences. Feed efficiency and partial efficiency were 0.77 (B) and 1.71 (A). These TMR resulted in satisfactory animal performance, but should be used with higher producing cows for better feed efficiency.
\end{abstract}

Key words: cows, hay, concentrate, total mixed rations

\section{RESUMEN}

Dos proporciones de heno a concentrado en raciones completamente mezcladas para vacas a diferentes etapas de lactación

Se compararon diferentes proporciones de forraje a concentrado en raciones completamente mezcladas (TMR), para vacas en etapa de lactación más temprana o más tardia en un experimento de dos fases (I y II). Durante I (120 dias), nueve vacas testigo apacentaron rotacionalmente en predios de gramineas no abonadas durante época de sequía y recibieron, en grupo, concentrados suplementarios (tratamiento A), mientras sus parejas en confinamiento recibieron una TMR compuesta de $40 \%$ de heno de gramíneas, del cual $25 \%$ fue finamente molido (FG) y $15 \%$ picado groseramente (CC), y $60 \%$ de concentrados (tratamiento B). Durante II (37 días), la TMR fue de $50 \%$ heno ( $35 \%$ FG y $15 \%$ CC) y $50 \%$ concentrados; el testigo (A) siguió como antes. Los resultados media para $\mathrm{A}$ y $\mathrm{B}$ en I fueron: producción diaria

'Manuscript submitted to Editorial Board 9 November 1993.

"Animal Nutritionist, Department of Animal Science. 
de leche, 16.1 vs. $17.8 \mathrm{~kg}$ y de leche corregida a $4 \%$ grasa (FCM), 11.4 vs. $14.9 \mathrm{~kg}$; concentraciones porcentuales en la leche de grasa (MF), 2.05 vs. 2.91 y proteína, 3.13 vs. 3.19 ; ganancia diaria en peso vivo (LW), 0.20 vs. 0.03 kg. Los tratamientos se difirieron $(P=0.01)$ en $F C M$ y MF. La ingestión de materia seca (DMI) en $B$ fue $18.2 \mathrm{~kg} /$ dia y la eficiencia alimentaria (FCM/DMI), 0.82; para A la DMI procedente de concentrados fue $7.3 \mathrm{~kg} / \mathrm{dia}$ y la eficiencia parcial (FMC/DMI de concentrados), 1.57. En Il, las medias de A y B fueron: producción de leche, 13.7 vs. $15.5 \mathrm{~kg} /$ dia; de $\mathrm{FCM}, 11.7$ vs. $13.6 \mathrm{~kg} / \mathrm{dia}$; MF, 3.07 vs. 3.22 ; ganancia en LW, 0.30 vs. $0.75 \mathrm{~kg} / \mathrm{dia}$, sin diferencias significativas. La eficiencia alimentaria y eficiencia parcial fueron 0.77 (B) y 1.71 (A). Estas TMR resultaron en buen desenvolvimiento animal durante dos etapas progresivas de lactación, pero deberían emplearse con vacas de mayor productividad para una mejor eficiencia alimentaria.

\section{INIRODUCTION}

In recent years many dairy farmers in Puerto Rico have adopted herd management in semi-confinement, with grazing time restricted and bulky concentrates used to compensate for deficient forage supplies and suboptimal fiber intakes. So far, only a few have adopted a feeding system based on total mixed rations (TMR) for cows in confinement, which is now common in such dairying regions as North America and Great Britain (Greenhalgh and Reid, 1980). However, in the future more local milk producers will probably find this alternative attractive, in view of the small area of the island and high land cost and favorable ratio of price received for milk sold to that paid for purchased concentrates.

Use of TMR containing $40 \%$ local grass hay and $60 \%$ concentrates (mostly imported) has given satisfactory results, except for low milk fat percentages in some cases (Randel, 1991; 1993). Since mechanical mixing and handling of the ration is facilitated by including only the minimal proportion of long-particle forage required, this aspect has been studied. Similar results were obtained in two separate experiments when the hay portion was all coarsely chopped (Randel, 1991) and when half chopped and half finely ground (Randel, 1993).

One objective of the present study was to determine whether a further improvement in mixing ease, achieved by including only $15 \%$ of chopped hay in the formula, combined with $25 \%$ of ground hay at the customary $40 \%$ total forage level, would be compatible with good performance of cows in early to mid lactation. The second objective was to test, at a later stage of lactation, a TMR designed to economize concentrates by decreasing the proportion of this component and increasing that of hay by $10 \%$ each. In both phases the control treatment consisted of rotational grazing in grass pastures and groupfeeding of supplemental concentrates. 


\section{MATERIALS AND METHODS}

\section{Phase I.}

Eighteen Holstein cows, which had calved from August thru October, were paired according to the two criteria, days postpartum and milk yield during five days precomparison period, and assigned at random within pairs to two treatment groups. The 120-day comparison period, beginning in early November 1989, was divided into four equal subperiods for purposes of milk and feed sampling and data summarization. The management routine of the control (treatment $\mathrm{A}$ ) involved group feeding of concentrates (Table 1) after a.m. milking in a shade barn, where the cows remained until p.m. milking. Thereafter and overnight, the animals grazed in 0.5 ha paddocks on mixed gramineous swards, at a stocking rate of $3 /$ ha, with rotation every four days among six paddocks. No fertilizer nor irrigation was applied to the pastures and grazing conditions deteriorated as the experiment progressed during four months of dry season. For this reason concentrate supplementation was not based on current production, but maintained in the range of $8-9 \mathrm{~kg}$ per head daily.

Treatment $\mathrm{B}$ cows were managed in confinement. After a.m. milking they were moved to an unpaved rest area with shade and water, but no feed available. Subsequent to p.m. milking they were placed in three pens of three animals each to receive their TMR (Table 1). The availability of only three pens for use in this experiment precluded the possibility of more replication of B. A low animal density in confinement was one of the measures used to avoid stress. The pens were located undex a saran shade, paved and equipped with watering cups and a roofed feed bunk, of adequate size such that all three cows could eat at the same time with little competition. The level of feeding was ad libitum (appreciable orts daily) during the adjustment period, which varied in length for different pens; it continued nearly so (a few days per pen without orts) during the first comparison subperiod; during subperiods 2 and 3 the daily offering was constant at $64 \mathrm{~kg}$ per pen $(21.3 \mathrm{~kg} / \mathrm{cow})$; and in subperiod 4 it remained at this same level in one pen, but was reduced to $60 \mathrm{~kg}$ in the other two pens of lower producing cows, to avoid unnecessary intake. Feed refusals were infrequent during the time of restricted offerings.

Coarsely chopped hay was obtained by passing baled material through a stationary machine with unsharpened blades that did more shredding than cutting. This resulted in particles varying greatly in size, including some as long as 15 to $20 \mathrm{~cm}$. The ground hay was hammex milled to pass a $3.175 \mathrm{~mm}$ screen. Three components of the TMR, 
TABI.E. 1.-Percentage formulas of supplemental concentrates and total mixed rations, analyzed chemical composition and theoretical energy values.

\begin{tabular}{|c|c|c|c|}
\hline \multirow[b]{2}{*}{ Ingredient or fraction } & \multirow{2}{*}{$\begin{array}{l}\text { Supplemental } \\
\text { concentrates }\end{array}$} & \multicolumn{2}{|c|}{ Total mixed ration } \\
\hline & & phase I & phase II \\
\hline Ground yellow maize' & 55.3 & 29.0 & 21.0 \\
\hline Wheat middlings & 32.5 & 12.2 & 8.9 \\
\hline Soybean meal & 4.5 & 10.4 & 11.8 \\
\hline Cane molasses & 6.0 & 6.4 & 6.4 \\
\hline Salt & 0.9 & 0.8 & 0.8 \\
\hline Urea & 0.4 & 0.7 & 0.7 \\
\hline Dicalcium phosphate & 0.4 & 0.5 & 0.5 \\
\hline Ground grass hay' & -- & 25.0 & 35.0 \\
\hline Chopped grass hay & - & 15.0 & 15.0 \\
\hline Dry matter & 85.5 & 88.6 & 88.2 \\
\hline Ash'2 $^{2}$ & 5.4 & 7.6 & 7.8 \\
\hline Crude protein ${ }^{2}$ & 16.3 & 14.0 & 13.1 \\
\hline Net energy for lactation² (Mcal/kg) & 1.90 & 1.55 & 1.46 \\
\hline
\end{tabular}

'Hammer milled through a $3.175 \mathrm{~mm}$ scieen.

Dry basis

concentrate premix, ground hay and chopped hay, were compounded in a revolving drum mixer ${ }^{3.4}$ However, a completely bomogeneous mixture could not be obtained because of separation of long hay particles from the finer material. At unloading, the latter tended to exit the mixer more rapidly.

Individual samples from two consecutive milkings were taken in each comparison subperiod and analyzed separately for fat and protein contents at the DHIA Central Laboratory of Puerto Rico. Calculation of milk composition took into account the milk weight at each milking. Feed samples, except pasture herbage, were also taken in each subperiod and analyzed for contents of dry matter (DM, oven drying at $60^{\circ} \mathrm{C}$ ), ash (incineration at $550^{\circ} \mathrm{C}$ ) and crude protein (CP, micro-Kjeldahl method). The cows were weighed after a.m. milking at the conclusion of subperiods 1, 3 and 4 (91 days from first to last weighing). All data from the full 120 days, and milk yield data per subperiod, were analyzed by paired t-test (Snedecor, 1956).

Roll-A-Mix, Model No. $80 \mathrm{cu}$. ft., Steiner Corp.

Trade names in this publication are used only to provide specific information. Mention of a trade name does not constitute a warranty of equipment or materials by the Agricultural Experiment Station of the University of Puerto Rico, nor is this mention a statement of preference over other equipment or materials. 
Phase II

The second comparison phase of 37 days duration began immediately after completion of the first. The two lowest producing control cows at that point (less than $10 \mathrm{~kg}$ of milk daily) were eliminated and the remaining seven continued on the same treatment as previously. The stocking rate in pasture was thus reduced to 2.5/ha. All nine confined cows continued under the same management, but received a TMR of different formula, containing $50 \%$ hay (35\% ground, $15 \%$ chopped) and $50 \%$ concentrates (Table 1 ). The daily offering was $20 \mathrm{~kg}$ per cow in all pens. Other procedural details were as described. Statistical analysis was by paired t-test using seven original pairs remaining intact.

\section{RESULTS AND DISCUSSTON}

During the final five days of adjustment, nine control cows had a mean daily milk production $0.08 \mathrm{~kg}$ higher than did those of treatment $\mathrm{B}$ (Table 2). The standard error (SE) of the former was more than double that of the latter, reflecting the fact that the three highest individual producers and the two lowest were all assigned at random to treatment A. Extreme values within treatment groups were from 24.1 to $12.0 \mathrm{~kg}$ and 20.3 to $15.1 \mathrm{~kg} /$ day. Between pair mates the largest difference in favor of treatment A was $5.1 \mathrm{~kg}$ and the largest in favor of $\mathrm{B}, 4.2 \mathrm{~kg}$.

In the first comparison subperiod, the lead in milk yield passed to $\mathrm{B}$ by a margin of $0.7 \mathrm{~kg}$ daily (Table 2 ), which constituted a net change between treatments relative to the final five days of adjustment of $1.5 \mathrm{~kg}$. Within-treatment variation remained unchanged throughout phase I in A and fluctuated only slightly in B. During the second through fourth subperiods the mean difference between treatments increased progressively to $0.9,2.0$ and $3.4 \mathrm{~kg}$. The SE of the mean difference exceeded the difference itself until subperiod 3 , and only in subperiod 4 did the $t$ value indicate a difference approaching significance $(\mathrm{P}=0.10)$. During this final subperiod all treatment $B$ animals still averaged at least 15 $\mathrm{kg}$ of milk daily and four of them exceeded $18 \mathrm{~kg}$. By contrast, four of the controls had low mean values of 12.7 to $7.8 \mathrm{~kg}$, although this was partially offset by three cows that exceeded $18 \mathrm{~kg}$. The $1.7 \mathrm{~kg}$ mean difference in favor of $\mathrm{B}$ over the full 120 days was not significant $(\mathrm{P}=$ $0.10)$.

Mean daily consumption of concentrates DM by the control cows remained within the limits of 7.6 to $6.8 \mathrm{~kg}$ per subperiod and was $7.25 \mathrm{~kg}$ over 120 days (Table 3 ). Intake of DM from TMR in B was less in subperiod $1(17.1 \mathrm{~kg})$ than in the subsequent subperiods $(18.6,18.9$ and 
TABI.E 2.-Mean daily milk production (kg) per treatment, mean differences and standard errors in successive stages of phase $I$.

\begin{tabular}{lcccc}
\hline & & \multicolumn{3}{c}{ Treatment } \\
\cline { 3 - 5 } Period & Days & $\mathrm{A}$ & $\mathrm{B}$ & Difference \\
\hline Adjustment & 5 & $18.4 \pm 1.4$ & $17.6 \pm 0.6$ & $0.8 \pm 1.0$ \\
Comparison & & & & \\
1 & 30 & $17.6 \pm 1.4$ & $18.3 \pm 0.7$ & $-0.7 \pm 1.4$ \\
2 & 30 & $17.0 \pm 1.4$ & $17.9 \pm 0.5$ & $-0.9 \pm 1.6$ \\
3 & 30 & $15.6 \pm 1.4$ & $17.6 \pm 0.5$ & $-2.0 \pm 1.6$ \\
4 & 30 & $14.0 \pm 1.4$ & $17.4 \pm 0.6$ & $-3.4 \pm 1.6$ \\
1 thru 4 & 120 & $16.1 \pm 1.4$ & $17.8 \pm 0.5$ & $-1.7 \pm 1.5$ \\
\hline
\end{tabular}

$18.1 \mathrm{~kg})$ reflecting lower appetite in spite of more liberal offerings. The 120 -day mean was $18.2 \mathrm{~kg}$. Assuming that $60 \%$ of this was concentrates, daily concentrates DM intake was $10.9 \mathrm{~kg}$.

Production of $4 \%$ fat-corrected-milk (FCM) during 120 days differed between treatments by $3.5 \mathrm{~kg}$ daily (Table 3 ). This superiority of $\mathrm{B}(\mathrm{P}=$ 0.01 ) resulted from the combined effects of higher milk production, cited above, and higher milk fat percentage. Mean difference between treatments in the latter $(0.86 \%)$ was also $P=0.01$. Eight of nine cows in treatment $A$ had mean milk fat percentages lower than 2.15, whereas among those of $\mathrm{B}$ only one was this low and three had values of 3.0 or greater. Thus, the control treatment clearly depressed milk fat, while $\mathrm{B}$ resulted in barely adequate fat concentration relative to the legal minimum (3\%). According to Gibson (1984), more frequent feeding of TMR (e.g. six times daily) has proven effective for increasing milk fat percentage when the proportion of forage is low, but not with rations containing $40 \%$ or more of forage DM, as in the present case. Nevertheless, this possible mechanism for improving milk composition might be worth evaluating under local conditions.

Milk fat production was also higher $(P=0.01)$, by $0.19 \mathrm{~kg} /$ day, in treatment $\mathrm{B}$ than in the control (Table 3 ). Thus, the difference between treatments was significant in all three criteria involving milk fat. By contrast, the corresponding differences in milk protein content and daily protein production $(0.06 \%$ and $0.07 \mathrm{~kg})$ did not approach significance $(\mathrm{P}=0.10)$.

Treatment $\mathrm{B}$ resulted in a minimal liveweight (LW) gain during the final 91 days of comparison (Table 3). On average, the control treatment registered an appreciable rate of gain, but this figure was due mainly to the three lowest producing cows, whose LW gain approached or exceeded $0.5 \mathrm{~kg}$ daily, whereas four of the higher producers showed slightly negative changes in LW. 
TABLE 3.-Mean daily results from nine pairs of cows during 120 days of comparison period, phase $I$.

\begin{tabular}{lcccc}
\hline & & \multicolumn{3}{c}{ Treatment } \\
\cline { 3 - 6 } Criterion & & A & B & Difference \\
\hline Dry matter intake from concentrates & $(\mathrm{kg})$ & 7.2 & 10.9 & -3.3 \\
Dry matter intake from TMR & $(\mathrm{kg})$ & - & 18.2 & - \\
Fat-corrected milk (4\%) production & $(\mathrm{kg})$ & 11.4 & 14.9 & -3.5 \\
Milk fat content & $(\%)$ & 2.05 & 2.91 & $-0.86^{*}$ \\
Milk fat production & $(\mathrm{kg})$ & 0.33 & 0.52 & $-0.19^{* \%}$ \\
Milk protein content & $(\%)$ & 3.13 & 3.19 & -0.06 \\
Milk protein production & $(\mathrm{kg})$ & 0.50 & 0.57 & -0.07 \\
Liveweight gain' & $(\mathrm{kg})$ & 0.20 & 0.03 & 0.17 \\
FCM/concentrates DM & $($ wt./wt.) & 1.57 & 1.37 & 0.20 \\
FCM/TMR-DM & (wt./wt.) & - & 0.82 & - \\
\hline
\end{tabular}

'During the latter 91 days.

: Significant $(\mathrm{P}=0.01)$.

Output of FCM per unit input of concentrates DM (partial feed efficiency) was $0.20 \mathrm{~kg}$ higher in the control than in treatment B (Table 3 ). This difference could not be tested statistically because of lack of replication of $\mathrm{A}$, but it represents a relative difference of $13 \%$ and is smaller than the advantages of treatments employing grazing over those based on confinement feeding of TMR found in previous experiments (Randel, $1991 ; 1993)$. In those experiments concentrate supplementation was adjusted to individual production rather than group fed as in the present case. The inefficiency of group supplementation for cows of widely varying production level was also indicated by the rapid LW gains of the lower milk producers.

Conversion of total dietary DM into FCM could be calculated only for treatment $B$, in which a value of 0.82 was obtained (Table 3). This is somewhat lower than the feed efficiencies of 0.93 and 0.89 observed previously (Randel, 1991; 1993) with TMR containing $40 \%$ of grass hay (all or half of it coarsely chopped) and $60 \%$ concentrates. However, pooling these three results gives a guideline value of $0.88 \mathrm{~kg}$ FCM/kg TMRDM for cows of mean FCM level not exceeding $15 \mathrm{~kg} /$ day. To put this in perspective the following example is offered. In a highly intensive system in temperate North America, TMR containing 40\% forage DM, from alfalfa haylage and alfalfa pellets, and $60 \%$ concentrates DM, sustained FCM yields of $25-30 \mathrm{~kg}$ daily and feed efficiencies of $1.30-1.37$ (Woodford and Murphy, 1988). The latter represents a relative advantage over the local results of about $34 \%$. 
During phase II, daily DM intake from concentrates was only $2.1 \mathrm{~kg}$ greater in treatment $\mathrm{B}$ than in $\mathrm{A}$ (Table 4). This difference smaller than previously resulted from reducing the proportion of concentrates in the TMR from $60 \%$ to $50 \%$, since the reduction in DM intake from TMR was no larger than that from control concentrates. Upon comparing milk yield during the final 30 days of phase $I$ (Table 2) with that of phase II (Table 4), a decrease of $1.9 \mathrm{~kg} /$ day (17.4 to 15.5 ) is noted for treatment $\mathrm{B}$ vs. only $0.3 \mathrm{~kg}$ (14.0 to 13.7) for A. However, this contrast is influenced by the fact that while the two lowest producers were eliminated from $A$, their pair mates were not the bottom cows in $B$. When all nine cows of treatment $B$ are included, mean production in phase II was 15.9 $\mathrm{kg}$ daily. Even so, $\mathrm{B}$ retained an advantage of $1.8 \mathrm{~kg}$ over the control based on seven cow pairs.

Milk fat content increased in both treatments in phase II relative to $\mathrm{I}$, but more so in A, reducing the difference between treatments to $0.15 \%$ (Table 4). The between-treatments difference in FCM yield differed only slightly from that of milk, but it approached significance $(P$ $=0.10$ ), and the latter did not. The difference between treatments in daily output of milk fat, of $0.08 \mathrm{~kg}$, was less than half of that of phase I (Tables 3 and 4). Percentage and daily yield of milk protein showed nearly the same differences between treatments as did milk fat. None of these differences approached significance $(P=0.10)$.

Mean daily LW increment of the seven control cows increased to $0.30 \mathrm{~kg}$ in phase II, but that of treatment B cows showed a steeper increase to $0.75 \mathrm{~kg}$. This figure should be viewed with caution because the

TABLE 4.-Mean daily results from seven pairs of cows during 37 days of comparison period, phase II.

\begin{tabular}{lccccc}
\hline & & \multicolumn{3}{c}{ Treatment } \\
\cline { 3 - 6 } Criterion & & $\mathrm{A}$ & $\mathrm{B}$ & Difference \\
\hline Dry matter intake from concentrates & $(\mathrm{kg})$ & 6.8 & 8.9 & -2.1 \\
Dry matter intake from TMR & $(\mathrm{kg})$ & - & 17.7 & - \\
Milk production & $(\mathrm{kg})$ & 13.7 & 15.5 & -1.8 \\
Fat-corrected milk (4\%) production & $(\mathrm{kg})$ & 11.7 & 13.6 & -1.9 \\
Milk fat content & $(\%)$ & 3.07 & 3.22 & -0.15 \\
Milk fat production & $(\mathrm{kg})$ & 0.42 & 0.50 & -0.08 \\
Milk protein content & $(\%)$ & 3.11 & 3.26 & -0.15 \\
Milk protein production & $(\mathrm{kg})$ & 0.43 & 0.50 & -0.07 \\
Liveweight gain & $(\mathrm{kg})$ & 0.30 & 0.75 & -0.45 \\
FCM/concentrates DM & $(\mathrm{wt} . / \mathrm{wt})$. & 1.71 & 1.54 & 0.17 \\
FCM/TMR-DM & $($ wt./wt.) & - & 0.77 & - \\
\hline
\end{tabular}


37-day interval was too short to reliably measure real LW changes, especially when the shift from $40 \%$ to $50 \%$ of hay in the TMR likely caused an increase in weight of gastrointestinal fill. Efficiency of utilizing concentrates for milk synthesis improved in both treatments relative to the previous experimental phase, whereas the mean difference in favor of A decreased by $0.03 \mathrm{~kg} F C M / \mathrm{kg}$ concentrates DM. However, a trend toward lower efficiency of converting TMR-DM to FCM was evident in phase II (Table 4). This is logical in view of the lower theoretical net energy value of the 50\% hay TMR (1.55 vs. 1.46), based on National Research Council (1978) tabular data (Table 1). Furthermore, the rapid LW gains suggest a tendency to partition nutrients into body reserves instead of milk secretion at this more advanced stage of lactation. Possibly the same milk yield could have been obtained and efficiency improved with less feed intake in B.

Although the second TMR was tested for only 37 days, these first results indicate that for cows in mid to late lactation the proportion of hay in rations of this type can be increased (40\% to $50 \%$ ) and CP content lowered slightly (14.0 to $13.1 \%$, dry basis) without accentuating the normal rate of decline in milk production. This finding constitutes one option for optimizing the contribution of local forages to dairy cattle feeding in confinement and reducing the reliance on imported concentrates. Another important consideration is that an improvement in hay quality would permit using a higher proportion of forage.

This possibility is demonstrated by a mean daily milk yield of $29 \mathrm{~kg}$ obtained by Hansen et al. (1991) with TMR containing $60 \%$ of excellent quality bromegrass hay. Other workers observed an increase in milk yield with decreasing acid detergent fiber content in alfalfa hays of variable quality, which constituted $50 \%$ of a TMR (Alhadhrami and $\mathrm{Hu}$ ber, 1992). Although not working with TMR, De Peters and Kesler (1980) showed that either $20 \%$ or $33 \%$ of a concentrates mixture, fed to cows yielding over $30 \mathrm{~kg}$ of milk daily and also receiving long alfalfa hay and maize silage, could be replaced by ground legume-grass hay of high quality without important effects on production.

On the basis of their experiments in Great Britain, in which TMR with grass hay: concentrate rations ranging from 40:60 to 70:30 were fed to cows of roughly the same production level as that of the present study, Greenhalgh and Reid (1980) concluded that for best economic results, the proportion of concentrates (and energy) should be reduced progressively with advancing stage of lactation. Israeli researchers stated that optimal formulation of TMR depends on economic conditions, notably the ratio of milk price to costs of concentrate and forage (Kroll et al., 1987). They also mentioned body condition as an impor- 
tant consideration, and recommended that cows past peak production which become too fat be switched to a lower energy TMR, whereas unduly thin cows continue to receive a higher energy ration, even when their current production no longer warrants this. From the animal health standpoint, Everson et al. (1976) reported benefits from the use of TMR with a variable forage (silage) to concentrate ratio, of 50:50 in early lactation and 65:35 in late lactation, relative to a constant 60:40, in terms of less LW loss at peak production, accompanied by higher blood glucose level and earlier postpartum estrus. Over the full lactation, intakes of total DM and of concentrates and milk production were closely similar.

In conclusion, both TMR of the present study resulted in satisfactory animal performance (generally superior to that of the control), but they involved more consumption of concentrates per unit of FCM produced. Clearly, this difference would become increasingly unfavorable for the TMR as grazing conditions improved in the control. Thus, heavy use of concentrates is one unavoidable disadvantage of feeding these TMR. One theoretical solution would be TMR based on harvested forage of very high quality, but local grass hay does not belong to that category. Even so, it should be possible to obtain at least $1.0 \mathrm{~kg}$ FCM from $1.0 \mathrm{~kg}$ TMR-DM, equivalent to $1.67 \mathrm{~kg}$ FCM per $\mathrm{kg}$ concentrates $\mathrm{DM}$ at a 40:60 forage to concentrate ratio, by using cows of $18 \mathrm{~kg} \mathrm{FCM} /$ day (or $21.2 \mathrm{~kg}$ of $3.0 \%$ fat milk) and with further refinement of the TMR. This represents a reasonable level of efficiency in concentrates utilization under local economic conditions. If this assumption is confirmed, the TMR system in question will be recommendable as one feasible option for use in commercial dairy farming.

\section{LITERATURE CITED}

1. Alhadhrami, G. and J. T. Huber, 1992. Effects of alfalfa hay of varying fiber fed at 35 or $50 \%$ of diet on lactation and nutrient utilization by dairy cows. J. Dairy Sci. 75:3091-9.

2. De Peters, E. J. and E. M. Kesler, 1980. Partial replacement of concentrates by high quality hay for cows in early lactation. J. Dairy Sci. 63:936-44.

3. Everson, R. A., N. A. Jorgensen, J. W. Crowley, E. L. Jensen and G. P. Garrington, 1976. Input-output of dairy cows fed a complete xation of a constant or variable forage-to-grain ratio. J. Dairy Sci. 59:1776-87.

4. Gibson, J. P., 1984. The effects of frequency of feeding on milk production in dairy cattle: an analysis of published results. Anim. Prod. 38:181-9.

5. Greenhalgh, J. F. D. and G. W. Reid, 1980. Complete diets for dairy cows: Comparison of feeding to appetite with rationship according to milk yield. J. Agric. Sci., Camb. 94:715-26.

6. Hansen, W. P., D. E. Otterby, J. G. Linn and J. D. Donker, 1991. Influence of forage type, ratio of forage to concentrate, and methionine hydroxy analog on performance of dairy cows. J. Dairy Sci. 74:1361-9. 
7. Kroll, O., J. B. Owen and C. J. Whitaker, 1987. Grouping and complete diet compusition in relation to parity and potential yield in dairy cows. d. Agric. Sci, Camb. 108:281-91.

8. National Research Council, 1978. Nutrient Requirements of Dairy Cattle, 5th ed., National Academy of Science, Washington, D.C.

9. Randel, P. F., 1993. Mixed chopped and ground grass hay for dairy cows vs. grazing plus concentrates, J. Agric. Uniu. P.R. 77:193-99.

10. Randel, P. F, 1991. Complete rations containing coarsely chopped or ground hay for dairy cows in confinement vs. conventional grazing. J. Agric. Univ. P.R. 75:241-52.

11. Snedecor, G. W., 1956. Statistical Methods. 5th ed., The Iowa State College Press, Ames, Iowa.

12. Woodford, S. T. and M. R. Murphy, 1988. Effect of forage physical form on chewing activity, dry matter intake, and rumen function of dairy cows in early lactation. $J$. Dairy Sci. 71:674-86. 